\title{
BÁCS-Bán Anetta
}

\section{A szakmai pedagógusok (pedagógusi) pálya elhagyásának vizsgálata több dimenzióban}

\author{
Nemzetközi és hazai kitekintés -elméleti alapvetések
}

\section{Bevezetés, problémafelvetés}

$\mathrm{Az}$ oktatás minőségének visszavezetése a pedagógusi munkára nemzetközi szinten pedagóguskutatások egész sorát indította el. Az OECD nemzetközi pedagóguskutatásai a pedagógusi szakmát komplex hivatásként értelmezve igyekeztek feltárni a pedagógusok pályára vonzásának és megtartásának lehetőségeit, valamint szakmai fejlődésük biztosításának feltételeit. (OECD, 2009.)

A fejlett országok egy része jelentős pedagógushiánnyal küzd. A nemzetközi jelentések az oktatás expanziójával és a pálya presztízsének csökkenésével a tanárhiányt komoly problémaként azonosítják (Mihály, 2002.). Annak ellenére, hogy Magyarországon - sok európai országgal ellentétben - nincs abszolút értelemben vett tanárhiány, hazánkban is megmutatkoznak ennek első jelei (Sági-Ercsei, 2012a és 2012b). A pedagógushiány, illetve a pályaelhagyás problémája azonban többnyire nem mennyiségi, hanem strukturális kérdés. Éppen ezért fontos a pályaelhagyók jellemzőinek és a pályaelhagyás okainak megismerése.

Jelen (nemzetközi és hazai szakirodalmi áttekintést adó) tanulmányunkban a szakmai pedagógusok körében végzett (tanulmányunk következő 2 . részében ismertetett) vizsgálatunk elméleti alapvetéseit fogalmazzuk meg. Vizsgálatunk köre a pályaelhagyó szakmai pedagógusok csoportja, azaz nem a pedagógusi pályán dolgozó mérnöktanárokat, múszaki szakoktatókat kérdeztünk meg kutatásunkban.

\section{Pályaelhagyás és annak okai}

A pályaelhagyás hazai és nemzetközi szakirodalmát áttekintve a szempontok sokaságát fedeztük fel. A későbbiekben bemutatott vizsgálatunkban ezen szempontok mentén kívántuk elemezni adatainkat, ezért ezek áttekintése elengedhetetlenül szükséges, a szakirodalmak jelentős része a pályaelhagyással foglalkozik s csak elenyésző hányaduk említi a szakmai pedagógusokat ezen összefüggésben.

\section{A pályaelhagyás fogalmának azonosítása}

A pályaelhagyás fogalmának meghatározása is nehézségekbe ütközhet, hiszen míg egy közismereti tanár esetében ez a kérdés könnyebben meghatározható, addig egy szakmai pedagógus pl. mérnöktanár esetében ez kevésbé egyértelmű. Pályaelhagyónak tekinthető-e az a mérnöktanár, aki vállalati környezetben oktatási feladatokat végez vagy az a mérnök, aki ugyan mérnöki pozícióban, de az újonnan belépők képzését szervezi és végzi?

A pályaelhagyás mint negatív kifejezés utalhat arra, hogy a tanult szakma elhagyása azért következik be, mert a képzési kibocsátási szerkezet nem megfelelő, vagyis már vagy még nincsen szüksége az adott 
végzettségre a munkaerő-piacnak. (Dávid-Horváth, 2010.) Későbbi elemzéseinkből látható azonban, hogy itt nem erről van szó, a munkaerő-piac, amely jelen esetünkben mind az oktatási rendszer, mind a gazdaság lehet (vállalatok, vállalkozások), sokkal nagyobb számú szakmai pedagógust tudna felvenni, mint a jelenlegi kibocsátás.

A pályaelhagyást Dávid-Horváth szerzőpáros (Dávid-Horváth, 2010.) szerint elsődlegesen nem azért kell problémának tekintenünk, mert így a tervezetthez képest hiány keletkezhet valamely szakmában, hanem azért, mert azt a veszélyt hordozza magában, hogy a pályaelhagyó későbbi karrierje során nem lesz képes olyan munkatevékenységet végezni, amellyel személyesen is tud azonosulni.

Azonban látható, hogy az oktatási rendszerben nagymértékű hiány mutatkozik a szakmai pedagógusokra vonatkozóan, ugyanakkor azt is érdemes lenne látnunk, hogy a gazdaság más területe azonnal felszívja őket, azaz a képzés önmagában hordozza a nagyfokú munkaerő-piaci konvertálhatóságot és lehetőséget.

A tanult szakmán kívüli elhelyezkedés a végzettség felhasználásnak rugalmas lehetőségét rejti magába, hiszen a tanulható szakmák túlnyomó többsége a munkakörök olykor szúkebb, máskor szélesebb skáláján alkalmazható. Azaz a jelenség jól leírhatóvá válik azzal, ha beazonosítjuk a képzettség hasznosságát, annak hasznosulásának mértékét. Az elemzés és a vizsgálat célja azonban nem a szakmai pedagógus képzés hasznosságnak vagy hasznosulásának leírása, csupán annak okainak feltárása, hiszen a keletkező szakember hiányt, valamely módon ellensúlyozni kell, s a jelenséget (pedagógusok pályaelhagyása) csökkenteni szükséges az oktatási rendszer strukturális tanárhiányának enyhítése okán.

A pályaelhagyás fogalmi tisztázása kapcsán még egy szempontot érdemes beemelni, jelesül azt, hogy a szakmai pedagógusok képzési-kimeneti követelményei (KKK) mit tartalmaznak, azaz milyen munkaerő-piaci státuszra pozícionáljuk a képzéssel őket. A szakmai pedagógusok körébe sorolt műszaki szakoktatók esetén csakúgy, mint a mérnöktanároknál egyaránt megjelennek a nemiskolarendszerű képzés terültéhez tartozó ismeretek, úgy, mint vállalati képzés, felnőttképzés. „A képzés célja müszaki szakoktatók képzése, akik a specializációjukhoz tartozó Országos Képzési Jegyzék szerinti müszaki szakmacsoportok területén felkészültek az iskolai rendszerü és az iskolarendszeren kivüli szakképzésben elsősorban a gyakorlati tárgyak oktatásának megtervezésére, szervezésére, vezetésére, valamint oktatási tevékenység végzésére, a szakmai tantárgyakhoz kapcsolódó laboratóriumi foglalkozások és a vállalati képzőhelyeken folytatott szakmai (üzemi, duális, tanmühelyi) gyakorlatok lebonyolítására, gyakorlati foglalkozások vezetésére..." (18/2016. (VIII. 5.) EMMI rendelet) Ezen összefüggésre a felnőttképzés, a felnőttoktatás vetületeiben Cserné mutat rá, de itt a pályaelhagyás kérdéseinél kihagyhatatlan ennek a szempontnak a beemelése is (Cserné, 2018.). Azaz újra feltehetjük a kérdést, hogy ha a képzés maga nem a pedagógusi pályára készít fel, hanem az iskolarendszeren kívüli, a vállalati képzés is a kimenet elemei között van, - ez pedig a mérnöktanárképzés kkk-jában már kezdettől fogva jelen van: „A képzés célja a felsőfokú müszaki képzésre alapozva $a z$ iskolai rendszerü és az iskolarendszeren kívüli, valamint az akkreditált szakképzésben az elméletigényes tantárgyak tanítására, a müszaki szakoktatás területén a pedagógiai kutatási, tervezési és fejlesztési feladatokra való felkészítés, továbbá a szakképzési irányultságú tudományos minősités megszerzésének megalapozása..."(A 15/2006 (IV.3.) OM rendelet 4. sz. melléklete) - akkor nevezhetjük-e pályaelhagyónak a nem iskolarendszerben dolgozó mérnöktanárokat. Tehát azt mondhatjuk, hogy adott esetben a fogalomhasználat: pályaelhagyás sem helyes esetükben, hiszen azon a pályán vannak, amelyre képzésük predesztinálta őket. 
Veroszta (2012) is rámutatott arra, hogy a tanári foglalkoztatástól jelentős strukturális távolságot mutat a mérnöktanárok munkavállalása. Hiszen jellemzően alacsony közalkalmazotti arány, a magánszféra átlagosnál nagyobb súlya, a külföldi tulajdonú, s az 1000 főnél nagyobb foglalkoztatottal működő munkáltatók aránya magas körükben. Azaz a mérnöktanárok a felsőfokú tanulmányaik során megszerzett ismereteket hasznosítják ugyan, de más szférában.

A Bologna-rendszer előtti főiskolai szintű mérnöktanár-képzés ezt még azzal is erősítette, hogy a végzett mérnöktanárok, - akik többségében képzésüket a mérnöki és pedagógiai területen ún. párhuzamos képzésben szerezték - kettős diplomát kaptak, azaz mind mérnöki, mind tanári végzettséget szereztek egyidőben. Ezen diplomákat nagyfokú munkaerő-piaci konvertálhatóság jellemezte/jellemzi a DPR vizsgálataink szerint (Bacsa-Bán, 2013.)

\section{A pályaelhagyás okai}

A pályaelhagyás okainak elemzésekor elsőként a társadalmi-demográfiai tényezőket vizsgálhatjuk, azaz az életkor, a pályán eltöltött idő és a nem kérdéseit. A kutatások azt bizonyítják, hogy az életkornak együttes hatása lehet a pályára lépéssel a pedagóguspálya elhagyására. (Sass, 2012) Egyes kutatók szerint a későn (40 éves kor felett) pályát kezdők kevésbé lesznek pályaelhagyók, mint fiatalabb pedagógustársaik (Hancock, 2008), ezt azonban részben az alacsonyabb bérekkel hozzák kapcsolatba, hiszen a fiatalon pályát kezdők szembesülhetnek azzal, hogy más foglalkozásokon magasabb kezdő bér is elérhető. A 40-50 év feletti korosztályt tekintik e vizsgálatok stabilnak, míg az 50 év felettieknél ismét növekszik a pályaelhagyás. A pedagógus életpálya bevezetése ellenére is egy középiskolai kezdő tanár bére és egy mérnök kezdőbére jelentős távolságot mutat. A profession.hu adatai alapján előbbi 180ezer Ft, míg utóbbi 250 ezer Ft nettó keresettel számolhat.

Jelen (a tanulmány második részében bemutatott) vizsgálatunk kis mintája (hangsúlyozottan nem reprezentatív) ugyan, de némi összefüggést megállapított az életkor és a pályán töltött évek száma között $(p=0,298)$, ugyanakkor ez csupán az életkorból is fakadhat.

A nemek tekintetében a szakirodalom ugyan lát összefüggést a pályaelhagyással kapcsolatban (Sass, 2012), ahol is a férfiak nagyobb pályaelhagyási magatartását azonosítják, leginkább azért, mert náluk mutatható ki a szakmával való nagyobb fokú elégedetlenség és az oktatás egyéb területei ( $p l$. adminisztráció) iránti fogékonyság. Azonban meg kell állapítanunk, hogy a szakmai pedagógusaink körében ez nem mutatható ki, semmilyen szignifikáns összefüggést nem hozott vizsgálatunk e tekintetben. Valószínúsíthető oka az, hogy maga a diploma speciális jellege eredményezheti azt, hogy akár nőként, akár férfiként lehetőség mutatkozik a mérnöki szakmai területeken való elhelyezkedésre, a más karrierút választására. Ezt azon eredményünk is alátámasztja, mely szerint a műszaki szakoktató végzettségú megkérdezettjeink zömmel pedagógusként dolgoztak, míg a mérnöktanári diplomával rendelkezők közel fele nem dolgozott pedagógusként. Más magyarországi vizsgálat sem látott összefüggést a pályaelhagyás és a nemek között (Varga, 2007.).

A szakirodalom arra is utal, hogy összefüggés található a között, hogy a diplomás, pedagógiai tanulmányait munka mellett végezte vagy a pályára lépéskor már rendelkezett pedagógusi diplomával. Ugyan vizsgálatunk a pedagógiai tanulmányok tagozatát kérdezte, de összefüggést nem találtunk a tényezők között, míg korábbi vizsgálataink (Bacsa-Bán, 2014.; Bacsa-Bán, 2015.) azt igazolták, hogy a „Bologna-rendszer" szerinti mérnöktanárképzés a pályán-maradást erősíti (csak 17,7\%-uk jelezte a pálya elhagyását illetve 12,9\%-uk tervezi azt). A képzést választók sokkal inkább a pedagógus pálya, a 
hivatásuk, szakmájuk szeretete, mint a végzettség kényszere okán maradnak, vagy néhány esetben kerültek a pedagógus pályára.

A pályaelhagyást a szakirodalom természetesen összefüggésbe hozza a tanított tárgyak, a pedagógusi specifikáció témakörével (Varga, 2007.), bár vizsgálatunk a tanított tárgyakra nem tért ki, de speciális csoportot vizsgált, hiszen a szakmai pedagógusok csoportja: legyenek azok mérnöktanárok vagy szakoktatók, valóban speciális képzési területet oktatnak. Képzettségük birtokában több feladattal szembesülnek munkájuk során, hiszen képzésük és végzettségük egyszerre több tárgy vagy tantárgycsoport, akár egy egész szakma oktatására készíti fel őket. S ismert tény, hogy ezen csoportok nagyobb arányban hagyják el mind a pedagóguspályát, mind az oktatás területét, pedig, ha nem is a formális oktatásban, de pl. a vállalati képzésben is jelentős szerep és feladat lenne rájuk szabható, hiszen beválás-vizsgálataink igazolták (Bán, 2006.; Bacsa-Bán, 2013.) hogy úgy szakmai, mint pedagógiai, azaz nevelés és oktatási ismereteik mindezt lehetővé teszik. Nemzetközi vizsgálatok igazolták, hogy a természettudományi tárgyakat tanító tanárok nagyobb valószínűséggel hagyják el a pályát, mint a más tárgyakat oktató középiskolai tanárok, valamint azt is jelezték az elemzéseik, hogy a pályát elhagyó tanárok nagyobb valószínűséggel specializálódtak valamilyen szakterületre (Paksi és mtsai, 2015a és 2015b). S ez vezet el a szakmai tanárok pályaelhagyásának okainak vizsgálatához is, hiszen ismert tény, hogy a pályaelhagyás magasabb számban jellemzi azon csoportokat, amelyek képesítése több foglalkozás betöltésére ad lehetőséget, és magasabb átlagfizetést is eredményezhet. A magyarországi pedagógusokra alkalmazva ennek szignifikáns összefüggéseit Varga mutatta be részletesen (Varga, 2007.).

Arra kérdésre, amelyben a tanári pálya elhagyásának fő tényezőit vizsgáltuk röviden a megkérdezettek leginkább a jövedelemmel való elégedetlenséget és a személyi körülményekkel való elégedetlenséget nevezték meg, s csak ezután következett a szakmai tartalom és a presztízselégedetlenség, s az olyan egyéb okok, mint pl. az elhivatottság hiánya, alkalmatlanság érzése, túlzott adminisztráció.

A pedagógusok pályaelhagyását vizsgáló országos felmérésben (Paksi és mtsai 2015a és 2015b) is ugyanerre a következtetésre jutottak.

A pedagógusi munka is egyértelműen meghatározó a jövedelmi helyzet alakulásában, ezen ismert összefüggésre már Veroszta is rámutatott (Veroszta 2012.), amely szerint a tanári pálya elhagyása szignifikáns jövedelem többletet eredményez; s vizsgálataiból is tudjuk, hogy a mérnöktanár pályaelhagyó kereseti előnye igen jelentős; valamint a munka szakmai, tartalmi része tekintetében is karrier előnnyel jár. Összességében a mérnöktanárok a felsőoktatásban tanult ismereteiket rugalmasan felhasználva, a közoktatás szférájától eltávolodva hasznosítják azt, amely számukra jelentős anyagi és elégedettség előnyökkel jár. 
1. ábra A jelenlegi és pedagóguskénti státusz eltérései
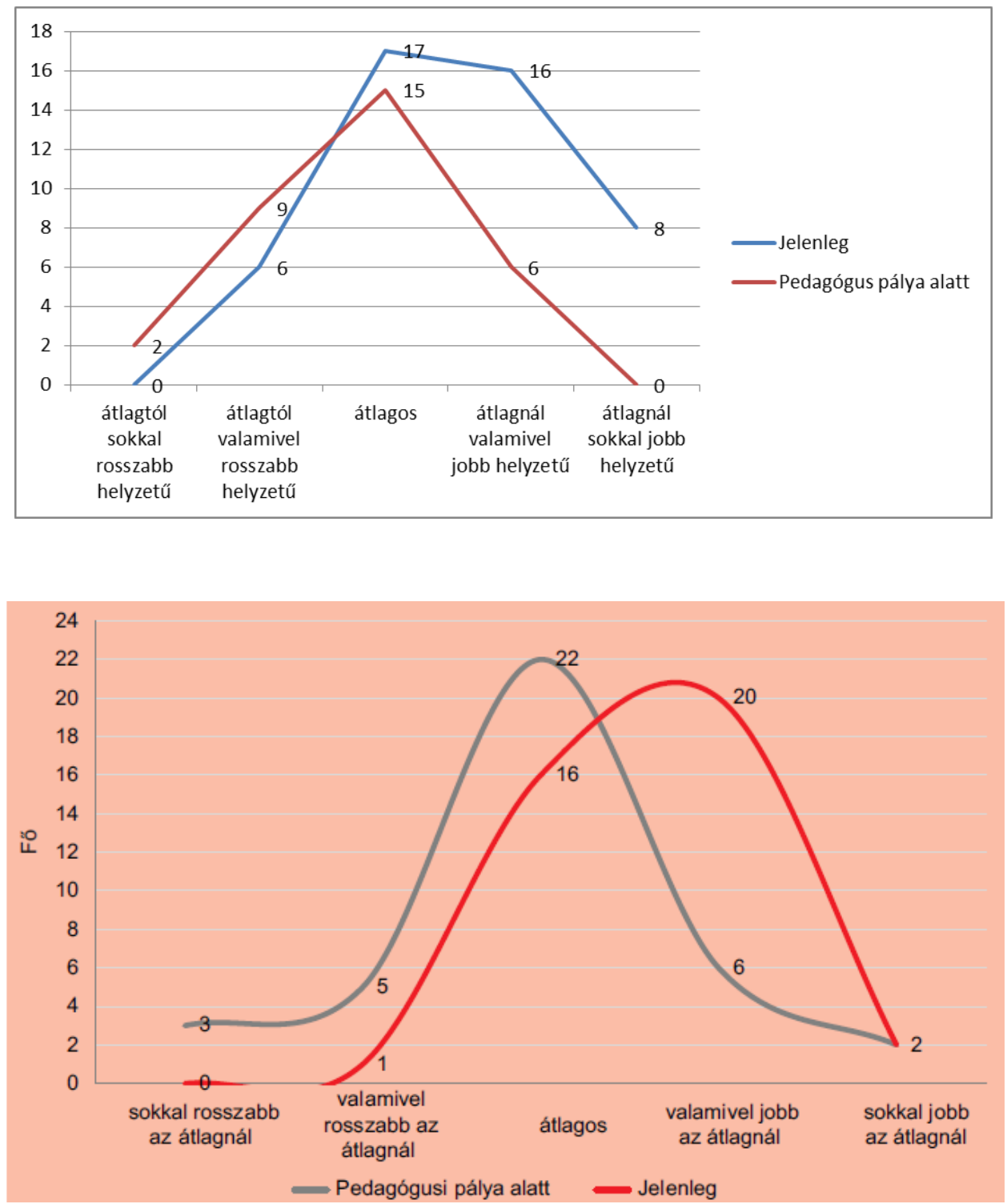

22. ábra Az országos vizsgálatban megkérdezettek gazdasági-társadalmi státuszának eltérései

Az ábrák alapján látható, hogy vizsgálati eredményeink szinte teljes mértékben megegyeznek az országos adatokkal, azaz szinte teljesen azonos tendencia rajzolódik ki a szakmai pedagógusok körében is úgy, mint az általánosan pedagógusok körében végzett vizsgálat során a társadalmi presztízs témakörében (Paksi és mtsai 2015a és 2015b).

\section{A pályaelhagyás és a pályán maradás körülményei}

A pedagógusok pályaelhagyásának okait feltáró vizsgálatok, csak úgy, mint a pedagógusok pályaválasztását és pályán maradását kutató írások középpontba állítják a tanári pályán maradást befolyásoló fő tényezőket. 
A speciális nevelési igényű tanulókat oktató pedagógusok körében felmérést végző Prather-Jones (2011a és 2011b.) 8 faktort azonosított a pályán maradás tényezői közül. A tényezőket két csoportba sorolta, egyéni jellemzők és az intézmény irányából érkező támogatások csoportjába.

3. ábra A pedagóguspályán maradás kétfaktoros modellje (Prather-Jones, 2010)

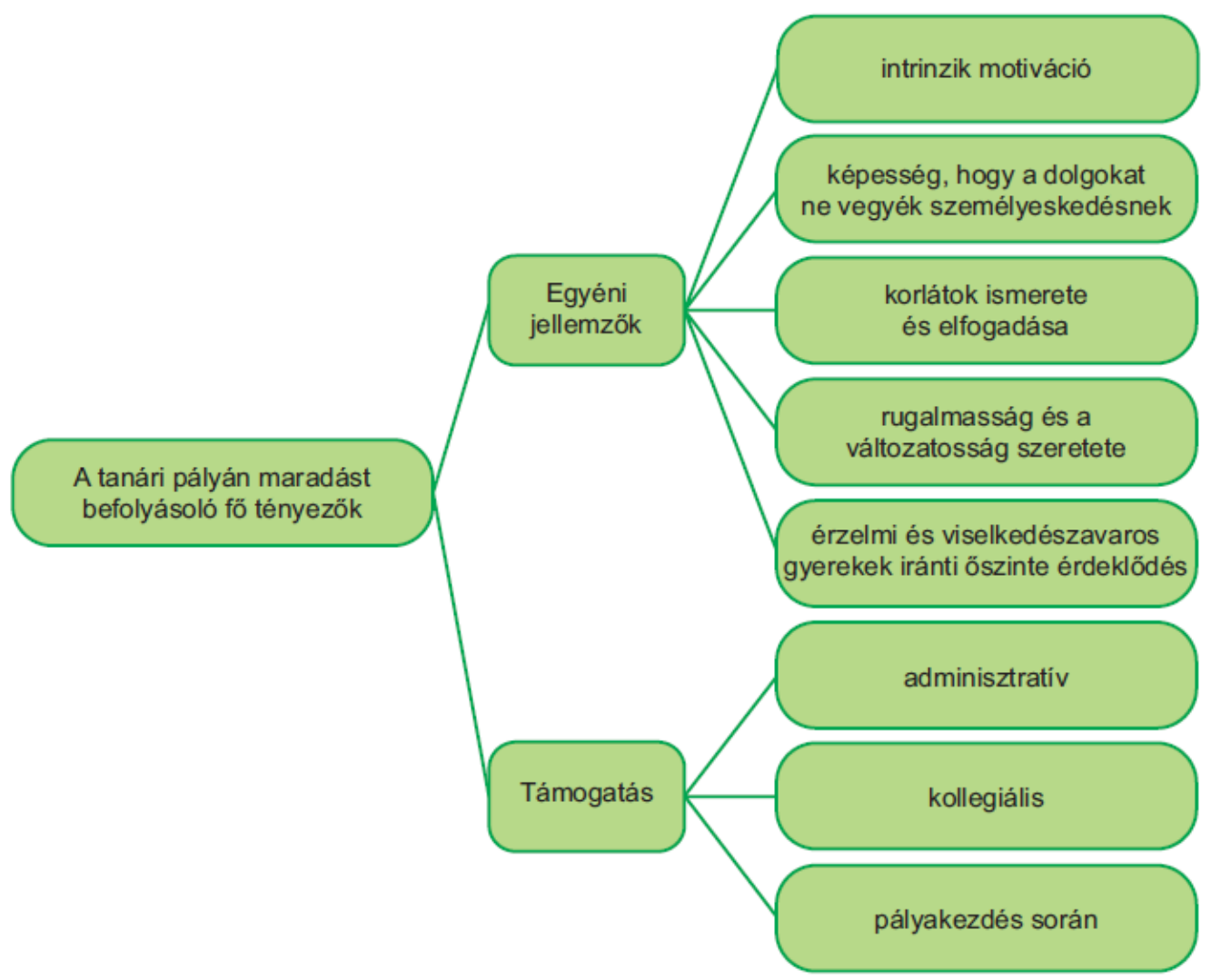

A pályán maradás modelljéhez számos szerző további faktort kapcsolt:

- elégedettség, mentális egészség (Berry, 2012.);

- pályakezdés során nyújtott támogatás (Parker-Ndoye-Imig, 2009.);

- kollegiális kapcsolatok, adminisztratív támogatás;

- segítő társszakmák (iskolapszichológusok) szerepe (Gallant 2009.).

Ezen szempontok mellé került a pedagógusokat foglalkoztató intézmények jellemzői, úgy, mint:

- munkaterhelés;

- osztály- és csoportlétszám;

- az intézményfenntartó típusa;

- az intézmény földrajzi elhelyezkedése;

- az iskolai légkör; 
- a kollegialitás szerepe;

- az egyéni támogatás mértéke;

- az intézményvezető szerepe és szervezeti bizalmi légkör;

- a diákok összetételének jellemzői. (Paksi és mtsai, 2015.)

A kutatások, mind hazai, mind nemzetközi szinten legfontosabb konzekvenciaként azt fogalmazták meg e témakörben, hogy a pályaelhagyás leginkább a pedagógusi pályával való elégedetlenséggel hozható összefüggésbe; azaz a pályaelhagyás legfőbb motiváló tényezője a pályával való elégedetlenség.

Néhány vizsgálatban arra is rámutattak, hogy a szakmai fejlődés lehetősége (Cha és Cohen-Vogel, 2011.) a pályaelégedettségre gyakorolt pozitív hatása erőteljes, csakúgy, mint a pálya presztízse, amely az elmúlt évtizedekben meglehetősen alacsony a pedagógus foglalkozások esetében, s presztízsvesztés magyarázhatja a pályaelhagyás mértékének nagyságát - ez utóbbira a későbbiekben még visszatérünk.

A pályaelhagyást Magyarországon is számos kutató vizsgálta, a vizsgálatok (Chrappán, 2012.; Veroszta, 2012.) fókuszba állítottak olyan pedagógus csoportokat, amelyek elégedettsége alacsony, s ezáltal pályaelhagyási aránya magas. E kutatások hívták fel a figyelmet a mérnöktanári, szakoktatói, általánosan is a szakmai tanári területekre a fent említett szempontok nyomán (Bacsa-Bán, 2014.).

Ha a pályaelhagyás magas, mit lehet tenni ellene? A pályán maradás egyik legfontosabb tényezője a pályaelégedettség (Chrappán, 2010.). A DPR-vizsgálatok során megkérdezett pedagógusok legkevésbé elégedett csoportjában jelentős számban voltak jelen a szakmai tanárképzésben részt vett volt hallgatók. Ennek oka nemcsak a pályaelhagyók elsődleges jövedelmi elégedetlensége, hanem a pedagógus diplomák eltérő konvertálhatósága is, ami a szakképzés területén jelentőssé vált. Bár megtörtént a pedagógus életpályamodell bevezetése, a tanári jövedelmek a szakképzésben még mindig messze elmaradnak egy ugyanolyan időtartamú alkalmazással versenyszférában szerezhető jövedelemtől (Chrappán, 2010.). Ez utóbbi tényt több tanulmány is megerősíti. (pl. Chrappán, 2012.). „A szakmai tanárok helyzete a legdiverzifikáltabb a pedagógusok között. Ennek oka részben a szakképzési ágazat természetes sokszínüsége, a körülötte zajló oktatásirányítási, pedagógiai és szakmai változások kavargása, de magyarázat lehet az is, hogy a szakoktatók pályamotivációs rendszere igen heterogén, amelyben a versenyszférával és az iskolával kapcsolatos elvárások keverednek." (Chrappán, 2012; 252.)

S ebből fakadóan is következtetik azt a fenti tanulmányok szerzői (Varga, 2007.; Mihály, 2010; Chrappán, 2010.; Chrappán, 2012.), hogy még mindig a tanári, a szakoktatói és a mérnöktanári diploma tûnik a piacon a legeladhatóbbnak. Erőteljesen köthető ide az a megállapítás is, hogy a szakmai tanárok/oktatók kettős identitásúak, szakmai és tanári identitással is rendelkeznek, amely foglakoztatási pozíciójukban az iskola és a munka-erőpiac számos területe között biztosít átjárást számukra. (Bükki, 2017.)

A pedagóguspálya választásának tényezőit elemezve (Varga, 2007.) azt tapasztalhatjuk, hogy a tanári pálya választása egy soktényezős, sokszereplős helyzet, amelynek legfontosabb állomásai: a pedagógusképzés választása, a végzést követően a pedagóguspályán való elhelyezkedés és végül döntés a pályán maradásról. 
A pedagógusok pályaelhagyását vizsgálva kiemelendő, hogy kisebb arányban találhatók tanári állásban azon végzettek, akik műszaki, informatikai, jogi, közgazdasági szakcsoportban szerezték diplomáikat. De összességében azok találhatók tanári állásban, akiknek kisebb a nem tanárként és tanárként elérhető keresetük között a különbség (Varga, 2007.). Ez igen fontos szemponttá emelkedik a szakmai tanárképzésben végzettek számára!

\section{A pályamotiváció}

A pedagógus pálya elhagyásának tényezőit vizsgálva a pályamotiváció témaköre is előtérbe kerül. Nemzetközi és hazai kutatásokból és elméletekből is ismert, hogy a pedagógus pálya választásának okai lehetnek külső (extrinzik) és belső (intrinzik) okok is. (Paksi és mtsai, 2015.)

Amelyek tovább bonthatók individuális okokra és a pedagógusi munkához/pályához köthető motivációkra. Ezen okok saját vizsgálatunkba is részben megjelentek. Az individuális belső motivációk pl. az önmegvalósítás nem, de a társadalmi hozzájárulás, a pedagógusi munka társadalmi szintű fontossága és a tudásátadás motivációja egyértelmúen jelen volt megkérdezettjeink válaszai közöttt. (Paksi és mtsai 2015a és 2015b) Csak úgy, mint a szakirodalmakban (Chrappán, 2012.; Kocsis, 2002.) oly sokat emlegetett gyermekszeretet is.

Az individuális külső motivációk közül a szabadság és a szabadidő jelentek meg mint motivációs tényezők. A szakmai fejlődés lehetősége és az állásbiztonság itt nem kapott szerepet, más vizsgálatokkal ellentétben (OECD, 2009., Klinic-Watt-Richardson, 2012.) és az értelmiségi karrier építésének lehetőségei sem jelentek meg (Nagy, 1998., Hajdú, 2001., Jancsák, 2010.), de a családdal, magánélettel való összeegyeztethetőség jelen volt (Butt-MacKenzie-Manning, 2010.).

Munkához köthető külső motivációs elemek pl., mint a korábbi tanítással /tanulással kapcsolatos pozitív tapasztalatokat éppen a nem-tanácsolás indokaként adták meg válaszadóink, a vélt munkáltatói elvárások, a tantestületi légkör, a munkakörülmények is ennek kapcsán merültek fel. Ezeket mind a hazai (Chrappán, 2012.; Kocsis, 2002., Varga 2010.), mind a nemzetközi szakirodalom (Manuel-Hughes, 2006.) említi.

Összességében a szakirodalom a pályán maradás és a pályaválasztás meghatározó tényezőinek az intrinzik motivációk meglétét hangsúlyozza. Azonban a 2013-2015 között végzett pedagógus-vizsgálat (Paksi és mtsai 2015a és 2015b) is megállapította a pályaelhagyókról, hogy az ő pályaválasztási döntésük leginkább 5 tényezőn alapult: a megfelelő képességek; a gyermekek/kamaszok jövőjének alakítása; a velük való munka fontossága, de a karrier belső értéke és a korábbi tanítási/tanulási tapasztalat is alakított pályaválasztási döntésüket.

Jelen vizsgálatunk is ezt erősítette, ahogyan ezt a továbbiakban látni fogjuk.

\section{A pedagóguspálya értékelése: a pálya elvárásai és elönyei}

A 2013-as országos vizsgálatban (Paksi és mtsai, 2015a és 2015b) is használt FIT-Choice-skálát használtuk e kérdéscsoport feltérképezésére. A FIT-Choice-skála (Factors Influencing Teaching Choice Scale (Richardson-Watt, 2006)) a szakirodalomban megjelenő motivációs elemeket széleskörüen lefedő, több európai országban is használt mérőeszköz. A 4. ábra a mérőeszköz hátterében álló modell elemeit szemlélteti. 


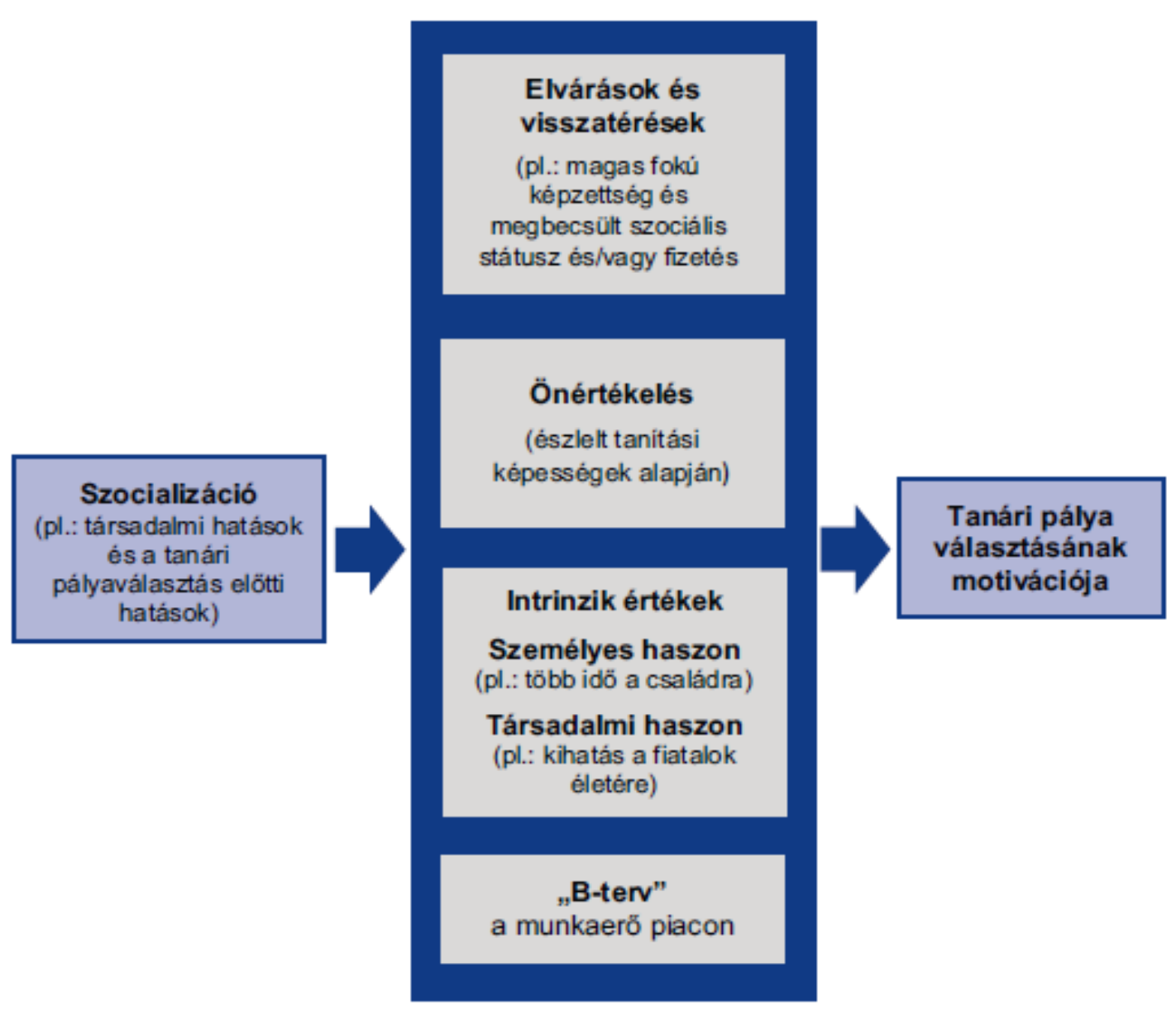

A modell számításba veszi a korábbi tapasztalatokat (pl. a pálya társadalmi megítélése, szülői ráhatás), melyek lefedik mindazt, ami már a tanítási gyakorlat előtt formálja a hallgatók pedagóguspályáról alkotott elképzeléseit. Ezt követően figyelembe veszi a következő tényezőket: (1) a feladattal kapcsolatos attitűdök (elvárások és jutalmak), (2) önmagukkal kapcsolatos attitűdök (saját képességek megítélése, énhatékonyság), (3) belső értékek (pl. a munka biztonsága, családdal töltött idő, társadalmi felelősségvállalás a gyerekekkel való munkán keresztül), (4) a pedagóguspálya, mint biztonságos másodlagos karrierút a munkaerőpiacon. A szerzők szerint ezekből a hatásokból tevődik össze az az egyéni érték, mely azt mutatja, hogy a hallgató mennyire elégedett, illetve mennyire motivált a pedagóguspálya-választással kapcsolatban. (Paksi és mtsai, 2015a és 2015b.)

A skála 57 elem és 18 faktor mentén rendeződik, amelyek nagyobb része a pedagógusi pálya motivációjával kapcsolatos, azonban a két faktor (a pálya elvárásai és a pálya előnyei) négy alfaktora (szakértelem, nehézség, társadalmi státus és fizetés) a pedagógiai pálya percepcióját jeleníti meg.

A FIT-Choice vizsgálatokat nemzetközi összehasonlításban is használják (7 fokú skálán mérve), s jól szembetűnik, hogy a magyarországi értékek közül a fizetésre adott pontszámok átlaga jelentősen eltér nagyságrendjében a más országokban tapasztaltaktól. A pályaelhagyás fő okaként megadott anyagi megbecsültségi problémák itt is visszatérnek. 
5. ábra A FIT-Choice skála egyes alskáláinak átlagértékei nyolc országban (Richardson-Watt, 2006) és Magyarországon (Paksi és mtsai, 2015a)

\begin{tabular}{|c|c|c|c|c|c|c|c|c|c|c|c|}
\hline & & 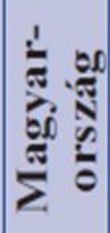 & $\frac{20}{\pi}$ & 先 & $\underset{\Xi}{\Xi}$ & $\begin{array}{l}\stackrel{4}{0} \\
\stackrel{2}{D}\end{array}$ & 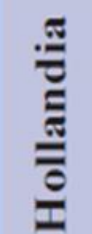 & 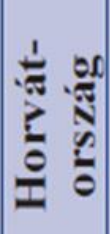 & 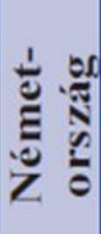 & $\frac{\pi}{\pi}$ & \\
\hline$\underset{2}{\pi}$ & Szakértelem & 6,19 & 5,17 & 5,24 & 2,77 & 5,41 & 5,25 & 5,76 & 5,76 & 5,86 & 5,32 \\
\hline$<\frac{2}{0}$ & Nehézség & 6,22 & 5,14 & 5,31 & 3,41 & 6,01 & 5,25 & 5,52 & 3,99 & 5,53 & 6,08 \\
\hline$\underset{2}{2}$ & $\begin{array}{l}\text { Társadalmi } \\
\text { státus }\end{array}$ & 3,92 & 3,91 & 4,18 & 3,13 & 4,33 & 3,28 & 3,58 & 4,42 & 4,31 & 4,08 \\
\hline$<\overline{0}$ & Fizetés & 2,86 & 3,53 & 3,24 & 3,53 & 2,49 & 3,29 & 3,21 & 4,42 & 4,72 & 3,33 \\
\hline
\end{tabular}

Természetesen nem kérdés, hogy a pályaelhagyást nem csak az anyagi okokkal lehet magyarázni, hanem egyéb jelentős individuális és intézményi okok is szerepet játszanak, mint pl. a korlátozott karrierlehetőségek, az adminisztratív terhek nagysága, a túlterheltség, a nem megfelelő munkafeltételek és a szakma presztízsvesztése is. (Veroszta, 2012)

\section{Összegzés}

A pedagóguspálya választásának tényezőit elemezve azt tapasztalhatjuk, hogy a tanári pálya választása egy soktényezős, sokszereplős helyzet, amelynek legfontosabb állomásai: a pedagógusképzés választása, a végzést követően a pedagóguspályán való elhelyezkedés és végül döntés a pályán maradásról.

A pedagógusok pályaelhagyását vizsgálva kiemelendő, hogy kisebb arányban találhatók tanári állásban azon végzettek, akik műszaki, informatikai, jogi, közgazdasági szakcsoportban szerezték diplomáikat. De összességében azok találhatók tanári állásban, akiknek kisebb a nem tanárként és tanárként elérhető keresetük között a különbség. Ez igen fontos szemponttá emelkedik a szakmai tanárképzésben végzettek számára!

A pályaelhagyás kockázata csökkenthető lenne. A pályaelhagyás visszafordítása, azaz a pedagógusi pályára való visszatérés elérhető, megfelelő oktatáspolitikai változtatások előidézhetik azt. A pályaelhagyás és a motiváció összefüggéseit érdemes lenne a képzésbe beépíteni, csakúgy, mint a pályán lévő gyakorló tanárok számára az életpálya modell részévé tenni. 
A 2013. szeptember 1-től bevezetett pedagógus előmeneteli rendszer célja a pedagóguspálya vonzóvá és kiszámíthatóvá tétele, a legjobb pedagógusok pályán tartása, a minőségi munka anyagi és nem anyagi honorálása, a pedagógusok motiválása, az oktatónevelő munka értékelésében országosan egységes rendszer kialakítása, a pedagógusi pálya presztízsének növelése, és végső soron a pedagógus hivatás megerősítésén keresztül a köznevelési rendszer minőségének javítása volt. Sági vizsgálataiban már kimutatta azt, (Sági, 2015a és 2015b.) hogy a szakképzésben dolgozó pedagógusok egyéni előrejutási lehetőségeiket tekintve nagyobb várakozással tekintenek a pedagógus életpályamodellre, mint a középiskolai tanárok. Az életpályamodell által jutalmazott képzettségek megszerzése a szakképzésben dolgozó pedagógusok körében dinamikusabb, esetenként hátrány-kompenzáló jellegű.

Ahhoz ugyanis, hogy a szakmát ismét jól képzett szakemberekkel lehessen feltölteni, valóban szükség lenne arra, hogy az életpályamodell vonzó legyen. Az anyagi megbecsültség növelése, a túlterheltség csökkentése, a megfelelő szakmai továbbképzések, megfelelő intézményi: tárgyi, infrastrukturális és személyi (segítői) környezet - ez mind csak a legelső lépése lenne annak, hogy újra fiatalokat lehessen a pályára vonzani és megtartani, motiválni a pedagógus pályán lévőket.

A 2007-es McKinsey jelentés szerint a sikeres oktatási rendszerek középpontjában a tanár áll, azaz az iskolarendszer minősége a tanárok teljesítményétől függ. (McKinsey, 2007.) Ugyanakkor - hamarosan látjuk kutatásunkból, hogy - a jól konvertálható szakmai pedagógusi (mérnöktanár, szakoktató) diplomát elszívják más ágazatok. A jövő szakképzése, a jövő szakemberei a most képzett szakmai tanárokra épülhet csak.

\section{Felhasznált szakirodalom}

- 18/2016. (VIII. 5.) EMMI rendelet a felsőoktatási szakképzések, az alap-és mesterképzések képzési és kimeneti követelményeiröl, valamint a tanári felkészítés közös követelményeiröl és az egyes tanárszakok képzési és kimeneti követelményeiről szóló 8/2013. (I. 30.) EMMI rendelet módositásáról

- 4. számú melléklet a 15/2006. (IV. 3.) OM rendelethez

- Bán Anetta - Mészáros Attila: A mérnöktanári diploma munkaerő-piaci értéke Szakképzési Szemle 19:(1) 2003. pp. 47-55.

- Bán Anetta: Eredmények, problémák és teendők a mérnöktanár-képzésben egy beválásvizsgálat alapján Szakképzési Szemle 22:(2) 2006. pp. 195-207.

- Bacsa-Bán Anetta: Mérnöktanár-képzés a pálya változó vonzásában In: Tóth Péter (szerk.) Empirikus kutatások a szakmai pedagógusképzésben. 191 p. Székesfehérvár: DSGI, 2013. pp. 5774.

- Bacsa-Bán: Mérnöktanárok a pedagóguspályán In: Ősz Rita (szerk.) Empirikus kutatások a szakképzésben és a felsőoktatás-pedagógiában. 235 p. Székesfehérvár: DSGI, 2014. pp. 41-52.

- Bacsa-Bán Anetta: Visszatekintő - a mérnöktanárképzés hallgatóinak és a képzés eredményességének longitudinális vizsgálata In: Bacsa-Bán Anetta (szerk.) Mérnöktanár: tradíció és modernitás: A 45 éves tanárképzés jubileumára. Dunaújváros: DUF Press, 2015. pp. 25-43.

- Benedek András - Szabóné Berki Éva: Szakmai tanárképzés-tradíciók és új késztetések. In: Szakmai tanárképzés: múlt - jelen - jövő Konferencia dokumentumok FKK Füzetek 7. Szerk.: Hrubos Ildikó, Pfister Éva: Nemzetközi felsőoktatási Kutatások Központja Corvinus Egyetem Közgazdaságtudományi Kar Budapest AULA Kiadó Kft. 2011. 
- Berry, Ann B.: The Relationship of perceived support to satisfaction and commitment for special education teachers in rural areas. Rural Special Education Quarterly, 31(1), 2012. 3-14.

- Butt, Graham - MacKenzie, Lin - Manning, Russell: Influences on British South Asian women's choice of teaching as a career: "You're either a career person or a family person; Teaching kind of fits in the middle". Educational Review, 62(1), 2010. 69-83.

- Bükki Eszter: A szakképzésben dolgozó pedagógusok folyamatos szakmai fejlődése a mesterpedagógus programok tükrében, Educatio 26 (2), 2017. pp. 299-306

- Cha, Sung-Hyun - Cohen-Vogel, Lora: Why they quit: A focused look at teachers who leave for other occupations. School Effectiveness \& School Improvement, 22(4), 2011. 371-392.

- Chrappán Magdolna: Elégedettség és mobilitási esélyek a pedagógusképzésben végzettek körében. In: Garai Orsolya et al. (szerk.): Frissdiplomások 2011. Educatio Társadalmi Szolgáltató Nonprofit Kft. 2012. 231-263.

- Chrappán Magdolna: Pályaelégedettség és karriertervek a pedagógus képzettségú hallgatók körében. In: Garai Orsolya et al. (szerk.): Diplomás pályakövetés IV. Friss- diplomások 2010. Educatio Társadalmi Szolgáltató Nonprofit Kft. 2010. 267-286.

- Cserné Adermann Gizella: A felsőoktatás hozzájárulása a lifelong learninghez - képzők képzése, Mellearn konferencia - Debreceni Egyetem, 2018. április 19-20.

- Dávid János - Horváth Gergely: Munkaerőpiaci esélyek és pályaelhagyás a szakmai képzés végzőseinek körében, Iskolakultúra 2010/1., 34-49.

- Gallant, Patricia A.: Kindergarten teachers speak out: „Too much, too soon, too fast!”. Reading Horizons, 49(3), 2009. 201-220.

- Hajdú Erzsébet: A harmadik évezred első nevelői lesznek. Új Pedagógiai Szemle, 51(9), 2001. 2535.

- Hancock, Carl B.: „Music Teachers at Risk for Attrition and Migration”. In: Journal of Research in Music Education, Vol. 56, No. 2 (July 2008), 130-144. o.

- Hercz Mária Siker és kudarc - a szakképzésben dolgozó tanárok képe önmagukról és tanítványaikról In: Kadocsa László, Buza Antal (szerk.) A Dunaújvárosi Főiskola Közleményei XXV. Dunaújvárosi Főiskola Kiadói Hivatala, 2013. pp. 113122.

- Jancsák Csaba: Értékválság és értékváltás a tanárképzős hallgatók világában. In Csíkos Csaba Kinyó László (szerk.): Új törekvések és lehetőségek a 21. századi neveléstudományokban. 10. Országos Neveléstudományi Konferencia. Program és összefoglalók. A konferencia helye és ideje: Budapest, Magyarország, 2010. november 4-6. Budapest, SZTE BTK Neveléstudományi Intézet; MTA Pedagógiai Bizottság, 222.

- Jancsák Csaba: A tanárképzésben részt vevő hallgatók felsőoktatási életútja a középiskolától a tanári oklevélig. Iskolakultúra, 14(5), 2014. 18-27.

- Kilinc, Ahmet - Watt, Helen, M. G. - Richardson, Paul W.: Factors influencing teaching choice in Turkey. Asia-Pacific Journal of Teacher Education, 40(3), 2012. 199-226.

- Kocsis Mihály: A tanárképzés megítélése, Iskolakultúra, Pécs, 2003. http://mek.oszk.hu/01800/01884/01884.pdf

- Manuel, Jackie - Hughes, John: „It has always been my dream”: Exploring pre-service teachers' motivations for choosing to teach. Teacher Development, 10(1), 2006. 5-24.

- McKinsey: How the world's best-performing school systems come out on top http://www.mckinseyonsociety.com/downloads/reports/Education/Worlds School Systems Final.pdf 2007. 
- Mihály Ildikó: Pedagógusok pályaelhagyása, Szakképzési Szemle XXVI. évfolyam 2010/1., p105110

- Mihály Ildikó: A tanári hivatás és a munkaerőpiac, Új Pedagógiai Szemle, 52. évfolyam, 2002. 6. szám. 90-99.

- Nagy Mária: A tanári pálya választása. Educatio, 1998(3), 527-542.

- OECD: Creating Effective Teaching and Learning Environments. First results from TALIS. Párizs, 2009, OECD. http://www.oecd.org/education/school/43023606.pdf

- Paksi Borbála - Veroszta Zsuzsanna - Schmidt Andrea -Magi Anna - Vörös András - EndrődiKovács Viktória - Felvinczi Katalin: Pedagógus - pálya - motiváció Egy kutatás eredményei, $\mathrm{OH}$, Bp. 2015. (2015a)

- Paksi Borbála - Veroszta Zsuzsanna - Schmidt Andrea -Magi Anna - Vörös András - Felvinczi Katalin: Pedagógus - pálya - motiváció II. kötet, OH, Bp. 2015 (2015b)

- Parker, Michele A.-Ndoye, Abdou-Imig, Scott: Keeping our teachers! Investigating mentoring practices to support and retain novice educators. Mentoring \& Tutoring: Partnership in Learning, 17(4), 2009. 329-341.

- Polónyi István: Pedagógusképzés - oktatásgazdasági megközelítésben. Educatio, 2004/3, 343358.

- Prather-Jones, Bianca: How school administrators influence the retention of teachers of students with emotional and behavioral disorders. The Clearing House: A Journal of Educational Strategies, Issues and Ideas, 84(1), 2011. 1-8.

- Prather-Jones, Bianca: Some people aren't cut out for it: The role of personality factors in the careers of teachers of students with EBD. Remedial and Special Education, 32(3), 2011. 179-191.

- Richardson, Paul W. - Watt, Helen M. G.: Who chooses teaching and why? Profiling characteristics and motivations across three Australian universities. Asia-Pacific Journal of Teacher Education, 34(1), 2006. 27-56.

- Sági Matild - Ercsei Kálmán: Kik akarnak tanári diplomát szerezni? Felsőoktatási Mühely, 2012/2, 51-73. (2012a)

- Sági Matild - Ercsei Kálmán: A tanári munka minőségét befolyásoló tényezők. In Kocsis Mihály Sági Matild (szerk.): Pedagógusok a pályán. 9-30. Oktatáskutató és Fejlesztő Intézet, Budapest (2012b)

- Sági Matild: Pedagógus karrierminták, Educatio, 2015/1., 83-97. (2015a)

- Sági Matild: Szakképzésben dolgozó pedagógusok változó környezetben, Szakképzési Szemle XXXI., 2015/1. 17-35. (2015b)

- Sass, Daniel A. - Flores, Belinda Bustos - Claeys, Lorena - Perez, Bertha: Identifying personal and contextual factors that contribute to attrition rates for Texas public school teachers. Education Policy Analysis Archives, 20(15), 2012. 1-30.

- Varga Júlia: „Kiből lesz ma tanár? A tanári pálya választásának empirikus elemzése”. In: Közgazdasági Szemle, 2007/7-8. szám, 609-627. o. http://www.mktudegy.hu/?q=system/files/VargaJ.pdf

- Varga Júlia: A pedagógusok munka- és munkaidő terhelése életkori kohorszok mentén. Kézirat. Budapest, 2010, Tárki-Tudok Zrt. http://www.t-tudok.hu/file/Pedteher/v_palyakezdok.pdf

- Varga: A McKinsey jelentés http://hirmagazin.sulinet.hu/hu/oktatas/a-mckinsey-jelentes, 2010

- Veroszta Zsuzsanna: A tanári pályaelhagyás szaktárgyi mintázata, Educatio 2012/4. 607-618. 